\title{
Sulphite binding in ciders
}

\author{
Basil Jarvis $^{* 1}$ \& Andrew G. H. Lea ${ }^{2}$ \\ 1 Ross Biosciences Ltd, Upton Bishop, Ross-on-Wye, HR9 7UR, UK \\ 2 Reading Scientific Services Ltd, The University, Whiteknights, Reading, RG6 6LA, UK
}

(Received 11 August 1999; Accepted in revised form 26 October 1999)

Summary The extent of sulphite binding was measured in commercial ciders, and experimentally observed binding curves were compared with theoretically derived curves based on assessment of the levels of individual sulphite binding compounds determined in the ciders. Subsequently, experimental ciders were fermented under various controlled conditions using nine different strains of cider yeasts. The results indicated considerable differences both in the levels of sulphite binding compounds produced, and in the ability of different yeast strains to produce $\mathrm{SO}_{2}$ in the cider. Juice concentration and the presence of cloud in juice had little or no effect on sulphite binding. Other factors which affected sulphite binding included the type and condition of juice (especially the effect of pectinase treatment) and, in some instances, the use of added yeast nutrients. Significant sulphite binding was also attributable to unaccountable components, probably derived from poor quality fruit, which were present in the apple juice prior to fermentation.

Keywords Cider, fermentation, sulphite, sulphite binding compounds, sulphur dioxide, yeasts.

\section{Introduction}

The use of sulphur dioxide in the production of wines and cider has a long and proven history and has been claimed to date back to Homeric times. Certainly it has been in use for cider making since the 17 th century, when its application in the form of sulphur candles was strongly recommended by Dr Beale writing in Evelyn's 'Pomona' (1664). It came into standard usage in the English cider industry during the 1950s, both in its application before fermentation to control the natural microflora of apples and to minimize oxidation of apple juice constituents, and in its use at bottling to prevent oxidative changes and to inhibit secondary infection. The chemistry and biochemistry of sulphur dioxide in fermented beverage systems is complex, and has been authoritatively reviewed on a number of occasions (see for instance Hammond \& Carr, 1976; Beech et al., 1979; Beech \& Davenport, 1983; Würdig, 1989). This paper deals only with its use after fermentation, and

*Correspondent: Fax: +44 1989 720154;

e-mail: basiljarvis@email.msn.com in particular with its efficacy in the presence of competitive binding components.

The phenomenon of sulphite binding has been identified previously (Burroughs \& Sparks, 1964, 1973a, b, c). Sulphur dioxide in ciders can exist in both free and bound forms, which are in equilibrium between each other to an extent depending on the concentration both of sulphite and of the binding components. These relationships are shown in Fig. 1(a) for a typical cider (based on data obtained during this study). The binding components may originate from the juice itself (e.g. galacturonic acid) or as a consequence of fermentation (e.g. acetaldehyde). For anti-microbial activity, only the free form of $\mathrm{SO}_{2}$ is effective, and only a very small portion of that, the so called 'molecular $\mathrm{SO}_{2}^{\prime}$ can actually enter susceptible micro-organisms and disable them at levels ca $0.5-1 \mathrm{mg} \mathrm{L}^{-1}$ (Hammond \& Carr, 1976; Würdig, 1989). The distribution between the molecular $\mathrm{SO}_{2}$ and the bisulphite anion is $\mathrm{pH}$ dependent, following the equilibrium $\mathrm{SO}_{2}+\mathrm{H}_{2} \mathrm{O} \leftrightharpoons \mathrm{HSO}_{3}{ }^{-}+$ $\mathrm{H}^{+}$, and is shown diagrammatically in Fig. 1(b) (Würdig, 1989). In practical terms, to achieve a target level of $50 \mathrm{mg} \mathrm{L}^{-1}$ free $\mathrm{SO}_{2}$ after bottling, 

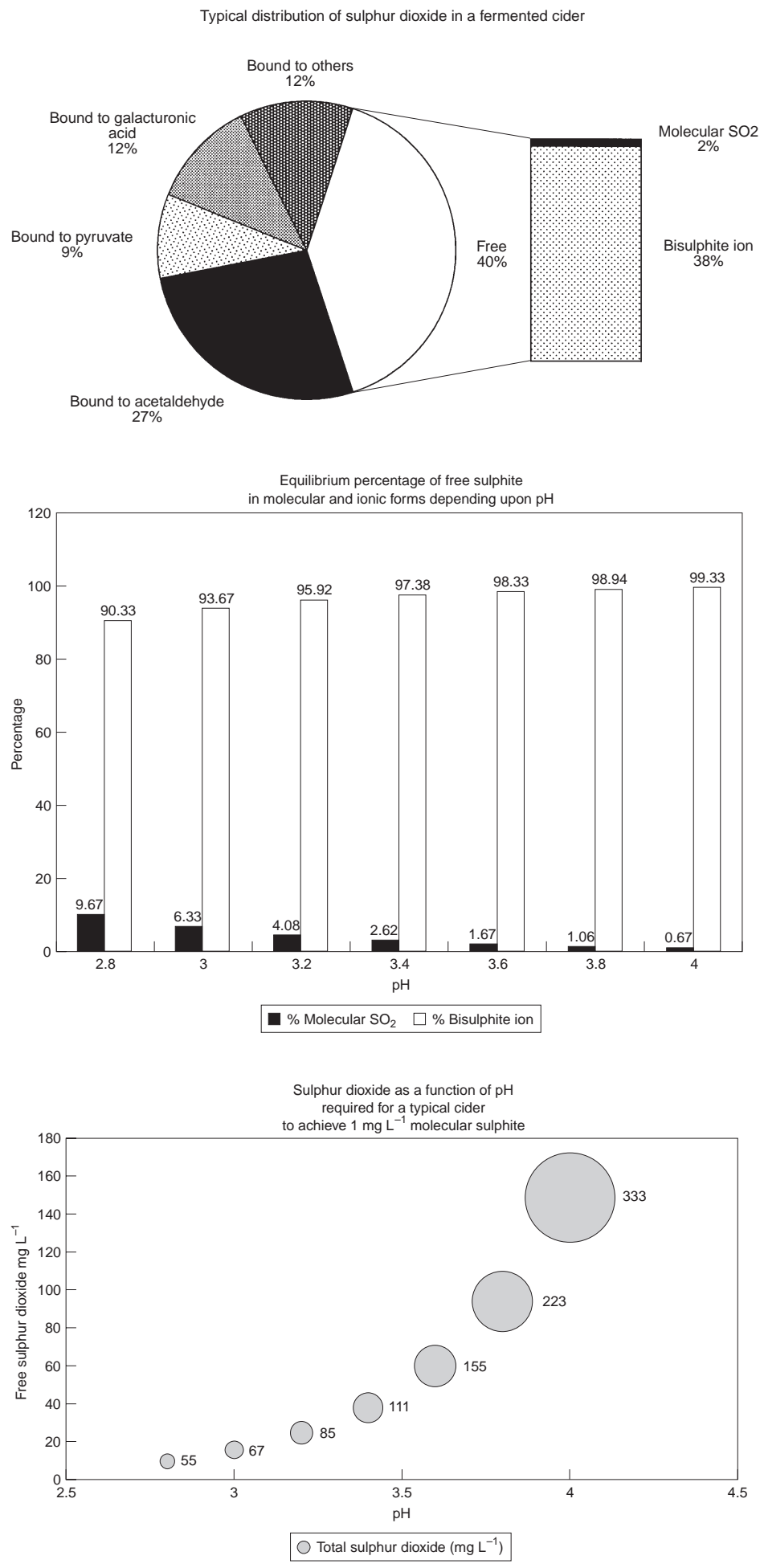

Figure 1(a) Typical distribution of sulphur dioxide in a fermented cider, (b) equlibrium percentage of free sulphite in molecular and ionic forms depending on $\mathrm{pH}$, (c) free and total sulphur dioxide required for a typical cider to achieve $1 \mathrm{mg} \mathrm{L}^{-1}$ molecular sulphite, as a function of $\mathrm{pH}$. 
equivalent to $1 \mathrm{mg} \mathrm{L}^{-1}$ molecular $\mathrm{SO}_{2}$ at $\mathrm{pH} 3.5$, it may be necessary to have a total level as high as 135 $\mathrm{mg} \mathrm{L}{ }^{-1}$. At higher $\mathrm{pH}$, more $\mathrm{SO}_{2}$ is required. These relationships are shown in the 'bubble plot' of Fig. 1(c) which is based on typical data obtained during this study - in this representation, the radius of each 'bubble' is proportional to the total amount of $\mathrm{SO}_{2}$ present, for each level of free $\mathrm{SO}_{2}$ which is shown on the y-axis. Since there is regulatory pressure to minimize the total quantity of sulphite used in foods, it is important to minimize the sulphite binding capacity of ciders as far as possible in order to have an adequate amount of free $\mathrm{SO}_{2}$ in the packaged product (Beech \& Jarvis, 1989).

\section{The sulphite binding components of cider}

It is well established that the dominant sulphite binding components of cider are those given in Table 1, ranked in order of known binding power (Burroughs \& Sparks, 1964). The binding power of individual components varies widely, and the equilibrium constant $(K)$ gives a measure of the intensity of sulphite binding, a smaller value indicating tighter binding and vice versa. Thus, although there is typically much more glucose in ciders than acetaldehyde, acetaldehyde makes a much greater contribution to sulphite binding than glucose. It is important to note that the binding power of acetaldehyde is so great that, in practice, no free $\mathrm{SO}_{2}$ can exist in a cider until all the acetaldehyde is bound. The other binding compounds exist in equilibrium between their bound and unbound forms. The individual calculations for sulphite binding are complex and are described in detail by Lea et al. (2000).

In general, the three major sulphite binders are those resulting from normal yeast metabolism during fermentation. These are acetaldehyde, pyruvate and $\alpha$-keto glutarate, which are referred to in this paper as 'metabolic carbonyls'. This is fortunate since potentially it allows us to manipulate a relatively controlled part of the cider making process. However, the importance of the other binders should not be forgotten. Galacturonic acid has classically been regarded as a minor binder and indeed its levels in traditional cider apple juice are low. It is present at much higher levels in apple juice concentrates, where it results from deliberate enzymic depectinization, so its contribution to modern ciders is greater than in the past. L-xylosone results from the breakdown of naturally occurring ascorbic acid in apple juice in the presence of $\mathrm{SO}_{2}$ during the prefermentation stage (Whiting \& Coggins, 1960) - little is known of its

Table 1 The key sulphite binding compounds likely to occur in cider

\begin{tabular}{|c|c|c|c|c|c|}
\hline Compound & Origin & $\begin{array}{l}\text { Equilibrium } \\
\text { constant* }^{*}(\mathrm{~K})\end{array}$ & $\begin{array}{l}\text { Typical concen- } \\
\text { tration in cider } \\
\left(\mathrm{mg} \mathrm{L}^{-1}\right)\end{array}$ & $\begin{array}{l}\text { Percentage } \\
\text { bound to } \mathrm{SO}_{2} \\
\text { (at } 50 \mathrm{mg} \mathrm{L}^{-1} \\
\text { free } \mathrm{SO}_{2} \text { ) }\end{array}$ & $\begin{array}{l}\mathrm{SO}_{2} \text { bound } \\
\text { (mg L} \mathrm{mg}^{-1} \text { ) } \\
\text { (at } 50 \mathrm{mg} \mathrm{L}^{-1} \\
\text { free } \mathrm{SO}_{2} \text { ) }\end{array}$ \\
\hline Acetaldehyde & Fermentation & $1.5 \times 10^{-6}$ & 25 & 99.8 & 35 \\
\hline Pyruvate & Fermentation & $1.6 \times 10^{-4}$ & 20 & 83 & 12 \\
\hline$\alpha$-Keto glutarate & Fermentation & $5.6 \times 10^{-4}$ & 15 & 58 & 4 \\
\hline L-Xylosone & $\begin{array}{l}\text { Ascorbic acid } \\
\text { breakdown }\end{array}$ & $1.4 \times 10^{-3}$ & 20 & 36 & 4 \\
\hline Galacturonic acid & $\begin{array}{l}\text { Pectin break- } \\
\text { down }\end{array}$ & $1.8 \times 10^{-2}$ & 1000 & 4 & 15 \\
\hline Glucose & $\begin{array}{l}\text { Sweetening } \\
\text { sugar }\end{array}$ & $6.4 \times 10^{-1}$ & 7000 & 0.1 & 8 \\
\hline $\begin{array}{l}\text { 5-keto fructose } \\
\text { (D-threo } 2,5 \\
\text { hexodiulose) }\end{array}$ & $\begin{array}{l}\text { Fungal and } \\
\text { bacterial activity } \\
\text { in mouldy and } \\
\text { poor quality fruit }\end{array}$ & $3.4 \times 10^{-4}$ & & 70 & \\
\hline \multicolumn{2}{|l|}{2,5 di-keto gluconic acid } & $4.4 \times 10^{-4}$ & & 64 & \\
\hline \multicolumn{6}{|l|}{ 5-keto gluconic acid } \\
\hline \multicolumn{6}{|l|}{ 2-keto gluconic acid } \\
\hline D glucuronic acid & & & & & \\
\hline
\end{tabular}

* Equilibrium constants are composites of various values taken from the literature (Würdig, 1989). 
typical levels in modern cider making. The five carbonyls produced by microbial activity in mould damaged fruit are known to contribute significantly to sulphite binding but should not be present at all in good quality fruit. Nothing is known of their presence in modern concentrates but their potential contribution should not be ignored. Methods for the measurement of sulphite binding compounds and the total sulphite binding capacity of ciders are described by Lea et al. (2000).

Improved understanding of those factors which affect the binding of sulphur dioxide might enable changes to be made to the formulation of cider juice bases and fermentation processes, to minimize the level of occurrence of sulphite binding compounds. The defined objectives of this study were to identify methods which could enable cider makers to reduce, or largely eliminate, sulphur dioxide binding compounds in juices and ciders, in order to reduce the usage of sulphur dioxide in cider making.

\section{Methods and materials}

\section{Analytical methods}

Juices, cider bases and fermented ciders were analyzed for the following: $\mathrm{pH}$ value, total and free sulphur dioxide, total and volatile acidity, residual sugar, residual gravity and alcohol using standard methods (NACM, 1996).

The levels of individual sulphite binding compounds, and the total sulphite binding capacity of the ciders, were determined using the methods described by Lea et al. (2000).

\section{Commercial ciders}

Twelve commercial ciders, typical of the types of product on the UK market, were purchased and assayed for their sulphite binding powers and for their content of carbonyls. The data were used to construct experimental and predicted sulphite binding curves.

\section{Yeast cultures}

Fermentations were undertaken using yeast strains from the National Association of Cider Makers (NACM) Culture Collection which is lodged with the National Collection of Yeast Cultures (NCYC) at the Institute of Food Research, Norwich. The strain reference numbers cited are those allocated by the NCYC.

\section{Yeast propagation}

Yeasts were propagated in a fortified apple juice medium containing $630 \mathrm{~mL}$ of commercial apple juice concentrate (AJC), $8 \mathrm{~g}$ di-ammonium phosphate and $5 \mathrm{~g}$ citric acid diluted with distilled water to 5 litres. After sterilization of the base medium by autoclaving, $100 \mathrm{~mL}$ of a filter sterilized solution containing $0.4 \mathrm{~g}$ sodium metabisulphite, $2 \mathrm{mg}$ thiamine hydrochloride and $1 \mathrm{mg}$ calcium pantothenate was added. Each yeast was inoculated into $10 \mathrm{~mL}$ complete base medium and grown for $24 \mathrm{~h}$ at $25^{\circ} \mathrm{C}$ while shaking; $1 \mathrm{~mL}$ of the culture was then added to $100 \mathrm{~mL}$ of the base medium and incubated for $48 \mathrm{~h}$ at $25{ }^{\circ} \mathrm{C}$ while shaking, followed by inoculation into $1 \mathrm{~L}$ of base medium which was incubated without shaking for $48 \mathrm{~h}$ at $25{ }^{\circ} \mathrm{C}$. This inoculum was then added to 5 litres base medium and sparged with sterile air for $20 \mathrm{~min}$; the cultures were grown for 4 days at $25{ }^{\circ} \mathrm{C}$ before harvesting by centrifugation. Purity and viability checks were made on the harvested yeast paste. In the third stage of fermentation studies the inoculum was prepared as a single batch of 20 litres. After harvesting by centrifugation, the yeast cells were 'acid-washed' at $<5{ }^{\circ} \mathrm{C}$ immediately prior to pitching. Yeast viability ranged from 80 to $99 \%$ in the different fermentations.

\section{Experimental fermentations}

Three sets of controlled fermentations were undertaken. In the first study, nine yeast strains representative of those used by UK cider makers were assessed in parallel fermentations using a standard cider fermentation base. For practical reasons, these were run as three sequential batches each of three separate yeast fermentations.

In the second stage, a standard juice was fermented with two yeast strains which, in the first stage, had given the highest (NCYC 5169) and one of the lowest levels of binding (NCYC 3627), respectively. Fermentations were conducted using a juice base with and without added nutrients at temperatures of 15,20 and $25^{\circ} \mathrm{C}$, thus giving a matrix of 12 different fermentations. These were run as three sequential 
batches of four parallel fermentations at a single temperature.

The third stage evaluated the difference between fresh and concentrated juices, prepared from bittersweet or culinary apple cultivars, clear (clarified) or cloudy, all fermented under identical conditions at $20{ }^{\circ} \mathrm{C}$. A matrix of eight systems was therefore investigated as two runs each of four parallel fermentations. The strain of yeast used (NCYC 5169) was that shown previously to produce the highest sulphite binding power.

\section{Controlled fermentations with nine cider yeast strains}

The base medium was prepared from a single supply of cider apple juice (previously stored frozen) to which was added malic acid $\left(1.0 \mathrm{~g} \mathrm{~L}^{-1}\right)$ and diammonium phosphate $\left(1.6 \mathrm{~g} \mathrm{~L}^{-1}\right)$. The base was pasteurised for $15 \mathrm{~min}$ at $70{ }^{\circ} \mathrm{C}$ and after cooling 15 litres were transferred through sterile pipes to each of three sterile 20 litre cylindro-conical fermenters. The level of $\mathrm{SO}_{2}$ was adjusted to a total sulphite level of $150 \mathrm{mg} \mathrm{L}^{-1}$ and the base was left overnight to stabilize. Thiamine hydrochloride $\left(0.42 \mathrm{mg} \mathrm{L}^{-1}\right)$ and calcium pantothenate $\left(0.2 \mathrm{mg} \mathrm{L}^{-1}\right)$ were added as sterile solutions. The base was sparged with air to give a dissolved oxygen level of $10 \mathrm{mg} \mathrm{L}^{-1}$. Each fermenter was pitched with a different yeast to give a cell count of $10^{7}$ cells $\mathrm{mL}^{-1}$ and the fermentation was allowed to proceed to dryness at $20{ }^{\circ} \mathrm{C}$. Samples were taken daily for chemical and microbiological analyses. At the end of fermentation, the cider was chilled to $3{ }^{\circ} \mathrm{C}$, racked off from the lees and stored at $0{ }^{\circ} \mathrm{C}$ prior to filtration through a sheet filter. Samples of the cider were bottled and pasteurized at 20PU prior to analysis. The experiment was performed on three occasions to provide a total of nine yeast fermentations.

\section{Controlled fermentations with two yeast strains at three temperatures in the presence and absence of added nutrients}

The fermentation base was prepared from a blend of apple juice concentrate and glucose syrup, stored at 0 ${ }^{\circ} \mathrm{C}$ until required for use. The composition of the base medium (SG $1.045^{\circ}$ ) was apple juice concentrate (5.12 L), HSS glucose syrup (3.60 L), citric acid (6.8 g) and water to $60 \mathrm{~L}$. Sodium metabisulphite was added to achieve a target level of $30 \mathrm{mg} \mathrm{L}^{-1}$ free $\mathrm{SO}_{2}$; after standing for $24 \mathrm{~h}$ further sulphite was added to the base medium to achieve the free $\mathrm{SO}_{2}$ target level. The base medium was then heated to 80 ${ }^{\circ} \mathrm{C}$, immediately cooled in line to the target temperature $\left(15,20\right.$ or $\left.25^{\circ} \mathrm{C}\right)$ and 15 litres were transferred to each of four 16 litre fermenters and aerated to achieve dissolved oxygen levels of 10 $\mathrm{mg} \mathrm{L}^{-1}$. In those experiments requiring yeast nutrients the following additions were made to 15 litre base medium prior to inoculation, to a target yeast cell count of $10^{7}$ cells $\mathrm{mL}^{-1}$ : Fermaid $9 \mathrm{~g}$; Diammonium phosphate $24 \mathrm{~g}$; Thiamine chloride 4.5 $\mathrm{mg}$; and Calcium pantothenate $2.25 \mathrm{mg}$.

Fermentations were stopped on attenuation or after 14 days. The ciders were chilled, filtered and packaged as described above, except that they were fined with bentonite prior to filtration. The fermentations were undertaken on 3 occasions, a different fermentation temperature $\left(15,20\right.$ or $\left.25^{\circ} \mathrm{C}\right)$ being used on each occasion.

\section{Controlled fermentation of bright and cloudy, fresh and concentrated culinary and bittersweet apple juices}

Bittersweet and culinary apple juices were taken direct from commercial pressings. Half of each volume was filtered to give a bright juice and half of each bright and cloudy juice was concentrated by evaporation under controlled low temperature conditions in the pilot plant at the Leatherhead Food RA. All juices and concentrates were held at $0-2{ }^{\circ} \mathrm{C}$ until required for fermentation. The fermentation bases were prepared as shown in Table 2 .

All base media were adjusted by addition of distilled water to an original gravity of 1.045 , heated to $80{ }^{\circ} \mathrm{C}$ and then immediately cooled to $20{ }^{\circ} \mathrm{C}$. Sodium metabisulphite was added to give a free $\mathrm{SO}_{2}$ level of $30 \mathrm{mg} \mathrm{L}^{-1}$ and the base media were

Table 2 Fermentation bases

\begin{tabular}{lll}
\hline Juices and concentrates & Fresh base & Concentrate base \\
\hline Fresh apple juice & 83.5 litres & - \\
Apple juice concentrate & - & 7.6 litres \\
Glucose syrup & 5.4 litres & 5.4 litres \\
Malic acid & to $\mathrm{pH} 3.3$ & to $\mathrm{pH} 3.3$ \\
Deionized water & - & to 90 litres \\
\hline
\end{tabular}


transferred aseptically to sterile fermenters. Yeasts were inoculated after $24 \mathrm{~h}$ to give a level of $10^{7}$ yeast cells $\mathrm{mL}^{-1}$. All fermentations were done at $20{ }^{\circ} \mathrm{C}$ and gravity was monitored daily. When attenuated, the fermented ciders were cooled to $4{ }^{\circ} \mathrm{C}$ and held for 2-3 days prior to racking off, fining, filtration, packaging and pasteurization at 40 PU's.

\section{Results}

\section{Occurrence of sulphite binding compounds in commercial ciders}

Table 3 gives the results of the carbonyl analyses, together with the predicted and experimental binding of sulphite at a nominal value of $50 \mathrm{mg} \mathrm{L}^{-1}$ free $\mathrm{SO}_{2}$. This value is chosen to allow easy comparisons across a wide range of samples. The detailed sulphite binding curves for two contrasting ciders are shown in Fig. 2.

In eight out of the 12 samples, agreement between the experimental and predicted curves was satisfactory. For instance in product 12, shown in Fig. 2, the discrepancy between the actual and predicted values of bound $\mathrm{SO}_{2}$ did not exceed $10 \mathrm{mg} \mathrm{L}^{-1}$. In three cases (products 7,9 and 10) the predicted curve lay considerably below the experimental curve and predicted only half the actual binding. In one case (product 5) both predicted and experimental curves were completely awry owing to the extremely high levels of acetaldehyde and pyruvate which were present. These were later attributed to the presence in this product of extremely high levels ( $c a 500$ $\mathrm{mg} \mathrm{L}^{-1}$ ) of ascorbic acid added before fermentation. It is not clear what effect this has on yeast metabolism but it is evidently dramatic. Although L-xylosone could not be analyzed at the time, retrospective evaluation of the chromatograms indicated a large peak running in the position of Lxylosone which may have been produced by ascorbate breakdown.

Of the remaining three samples in which discrepancies were evident (e.g. product 9 shown in Fig. 2), there appeared to be no common feature in the high performance liquid chromatography (HPLC) traces. It was suggested that the presence of one or more of the following could be involved: anthocyanin extract (one of these samples was coloured with blackcurrant); caramel colour; synthetic azo dye colours; saccharin; hydroxymethyl furfural and other carbonyls generated in stored concentrate; keto sugars (from fruit in poor condition). It is important to remember that the identification of 'classical' sulphite binders by Burroughs \& Sparks (1964, $1973 \mathrm{a}, \mathrm{b}, \mathrm{c})$ was carried out at a time when these materials were not in commercial use and, apart from the keto sugars, nothing is known of their sulphite binding potential.

An unexpected observation was that the free galacturonic acid levels in commercial ciders could be as high as $2000 \mathrm{mg} \mathrm{L}^{-1}$, and in several cases provided the second highest total binding capacity
Table 3 Carbonyl analysis and sulphite binding power of commercial ciders

\begin{tabular}{|c|c|c|c|c|c|c|c|}
\hline \multirow[t]{2}{*}{$\begin{array}{l}\text { Sample } \\
\text { code }\end{array}$} & \multicolumn{5}{|c|}{ Concentration of binders $\left(\mathrm{mg} \mathrm{L}^{-1}\right)$} & \multicolumn{2}{|c|}{$\begin{array}{l}\text { Bound } \mathrm{SO}_{2}\left(\mathrm{mg} \mathrm{L}^{-1}\right) \\
\text { at } 50 \mathrm{mg} \mathrm{L}^{-1} \\
\text { free } \mathrm{SO}_{2}\end{array}$} \\
\hline & $\begin{array}{l}\text { Acetal- } \\
\text { dehyde }\end{array}$ & Pyruvate & $\begin{array}{l}\alpha \text {-keto } \\
\text { glutarate }\end{array}$ & $\begin{array}{l}\text { Galactur- } \\
\text { onic acid }\end{array}$ & Glucose & Predicted & Actual \\
\hline 1 & 9 & 6 & 40 & 515 & 4180 & 35 & 48 \\
\hline 2 & 20 & 3 & 2 & 994 & 14700 & 50 & 55 \\
\hline 3 & 23 & 17 & 23 & 876 & 10700 & 65 & 60 \\
\hline 4 & 30 & 33 & 49 & 1010 & 6520 & 91 & 88 \\
\hline 5 & 128 & 927 & 223 & 953 & 3000 & 816 & $\infty$ \\
\hline 6 & 10 & 4 & 12 & 891 & 5180 & 33 & 40 \\
\hline 7 & 23 & 10 & 15 & 640 & 6380 & 54 & 82 \\
\hline 8 & 15 & 20 & 32 & 1040 & 7830 & 58 & 66 \\
\hline 9 & 15 & 4 & 9 & 379 & 7390 & 34 & 78 \\
\hline 10 & 13 & 15 & 17 & 672 & 7740 & 43 & 75 \\
\hline 11 & 45 & 45 & 60 & 599 & 5710 & 117 & 105 \\
\hline 12 & 38 & 15 & 22 & 2030 & 7250 & 99 & 89 \\
\hline
\end{tabular}


Figure 2 Sulphite binding curves for two contrasting commercial ciders (products 9 and 12).

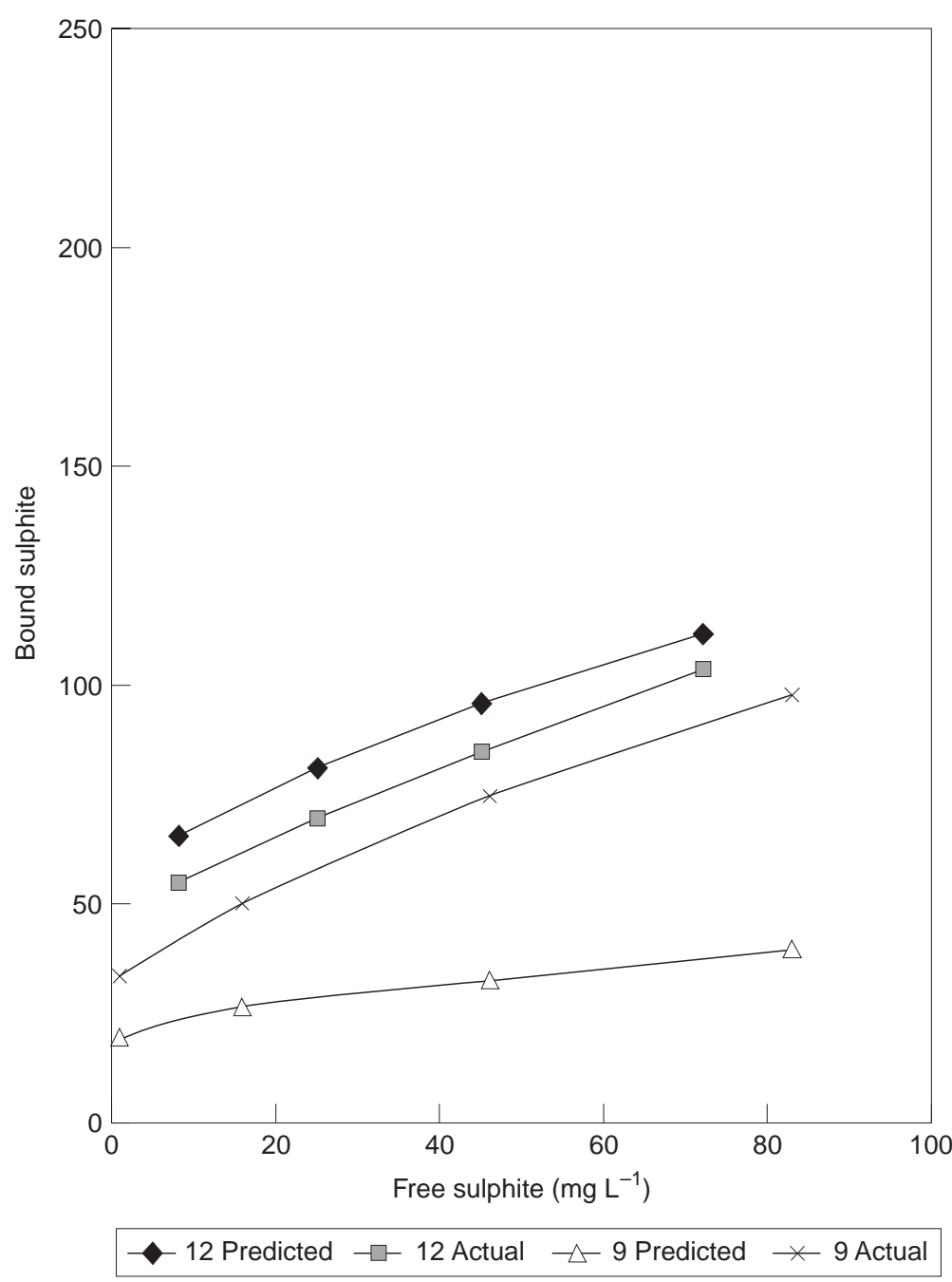

after acetaldehyde. This reflects directly the use of depectinized apple juice concentrate in modern cider making.

\section{Controlled fermentations using nine cider yeast strains}

\section{Fermentation data}

Microbiological analyses on the yeast inocula showed no significant evidence of contamination. The cider bases all showed a low level contamination with filamentous fungi and short bacterial rods (probably Bacillus spp) which had survived pasteurization. After fermentation, the ciders generally contained low levels of bacteria and wild yeasts.

The fermentations proceeded rapidly, generally attenuating (i.e. fermenting to $\mathrm{SG} \leq 1.0000$ ) after 7-8 days, and one strain (NCYC 2347) had fermented out within 3 days although strain NCYC 3627 required 12 days to attenuate. At the end of fermentation, the levels of alcohol produced and residual sugar levels varied between strains as did the sulphite binding power of the ciders (Table 4 ). The production of $\mathrm{SO}_{2}$ during fermentation also appeared to vary between yeast strains.

\section{Sulphite binding}

Experimental sulphite binding power was compared with the predicted values from carbonyl analyses. For calculation, levels of the three metabolic carbonyls were taken into account (which varied considerably 
Table 4 Analytical data from the nine cider fermentations

\begin{tabular}{|c|c|c|c|c|c|c|c|c|}
\hline \multirow{3}{*}{$\begin{array}{l}\text { Yeast } \\
\text { strain } \\
\text { (NCYC) }\end{array}$} & \multirow{3}{*}{$\begin{array}{l}\text { Time to } \\
\text { attenuation } \\
\text { (hrs) }\end{array}$} & \multirow{3}{*}{$\begin{array}{l}\text { Residual } \\
\text { gravity } \\
\text { (degrees } \\
\text { Sacch) }\end{array}$} & \multicolumn{6}{|l|}{ Cider analysis } \\
\hline & & & \multirow[t]{2}{*}{ Alcohol (\%v/v) } & \multirow[t]{2}{*}{$\begin{array}{l}\text { Sugar } \\
(\% \mathrm{w} / \mathrm{v} \text { as } \\
\text { sucrose })\end{array}$} & \multirow[t]{2}{*}{$\begin{array}{l}\text { Acidity } \\
\text { ( } \mathrm{mEq} / \mathrm{L}^{-1} \\
\text { as malic) }\end{array}$} & \multirow{2}{*}{$\begin{array}{l}\text { Total } \\
\mathrm{SO}_{2} \text { in } \\
\text { cider } \\
\left(\mathrm{mgL}^{-1}\right)\end{array}$} & \multicolumn{2}{|c|}{$\begin{array}{l}\text { Sulphite bound } \\
\left(\mathrm{mgL}^{-1}\right) \text { at } \\
45 \mathrm{mg} / \mathrm{l} \text { free } \mathrm{SO}_{2}\end{array}$} \\
\hline & & & & & & & Predicted & Actual \\
\hline 3627 & 260 & 2.7 & 4.99 & 0.24 & 68 & 43 & 92 & 142 \\
\hline 9012 & 240 & 4.1 & 5.19 & 0.31 & 80 & 31 & 82 & 123 \\
\hline 5832 & 190 & 2.4 & 5.15 & 0.61 & 74 & 72 & 95 & 158 \\
\hline 0862 & 170 & 2.2 & 5.37 & 0.25 & 76 & 51 & 99 & 142 \\
\hline 2166 & 168 & 2.4 & 5.10 & 0.31 & 67 & 62 & 87 & 158 \\
\hline 4467 & 145 & 1.9 & 4.93 & 0.30 & 72 & 70 & 132 & 178 \\
\hline 5169 & 90 & 2.4 & 5.00 & 0.45 & 79 & 104 & 142 & $>200$ \\
\hline 4704 & 75 & 2.2 & 5.33 & 0.32 & 83 & 48 & 82 & 157 \\
\hline 2347 & 96 & 2.2 & 5.37 & 0.32 & 78 & 72 & 121 & 170 \\
\hline
\end{tabular}

between yeast strains), together with those for galacturonic acid and L-xylosone (which were constant at 200 and $55 \mathrm{mg} \mathrm{L}^{-1}$ respectively and derived from the original juice). In these fermented unsweetened ciders the level of glucose was trivial.

Three features were immediately evident from the data, presented in Table 4. Firstly, the binding power of the ciders varied nearly twofold across the range of yeasts used, strain NCYC 5169 producing the greatest and strain NCYC 9012 the lowest binding power. Secondly, the shapes of the binding curves, which are presented in Fig. 3 for NYC 5169 and 9012, were much steeper than those obtained for the commercial ciders analyzed previously - i.e. the binding power per unit volume of the experimental ciders was much greater. This reflects the fact that commercial ciders are usually 'broken back' (i.e. diluted) with water after fermentation to achieve the required alcohol level, thus reducing their final sulphite binding power, whereas these pure juice ciders were not diluted. Thirdly, the agreement between predicted and experimental binding was poor and typically predicted only $50 \%$ of the experimentally observed value.

To eliminate the possibility of experimental error in the determinations, the HPLC determinations of the metabolic carbonyls were replicated by enzymic methods and similar values were obtained. Since there appeared to be a common discrepancy between all nine samples, suspicion therefore lay with the juice itself. Unfortunately no reference sample of the original juice (1993 season) was available for study and therefore samples of a similar blended bittersweet juice from the following season (1994) were examined. The binding power of this juice did not differ between pasteurized and deep frozen samples, thus eliminating any influence from pasteurization. However, the experimental binding power was much higher than could be accounted for by levels of the only known carbonyls in the juice (glucose and acetaldehyde), and was much higher than previously observed by Burroughs \& Sparks (1962) in studies of sound bittersweet cider juices. In practice, virtually no free $\mathrm{SO}_{2}$ could be obtained even at $200 \mathrm{mg} \mathrm{L}^{-1}$ total $\mathrm{SO}_{2}$. Even when the binding measurements were carried out by direct iodine titration (the Ripper method) similar results were obtained and it was therefore evident that the methodology was sound and that the juice itself truly contained unknown binding compounds.

Inspection of the HPLC chromatograms (Fig. 4) indicated that in the 1994 juice and in the nine ciders fermented from 1993 juice there were two significant peaks preceding acetaldehyde, which had not been observed previously in chromatograms of bittersweet ciders. By inference, these peaks may have been responsible for the additional sulphite binding which was determined. They cannot be attributable to pasteurization, to concentration or to any additives, since none were used. It is therefore possible that they are associated with poor quality fruit, and that these unknown peaks may correspond with the 
Figure 3 Sulphite binding curves for yeast strains NCYC 5169 and 9012.

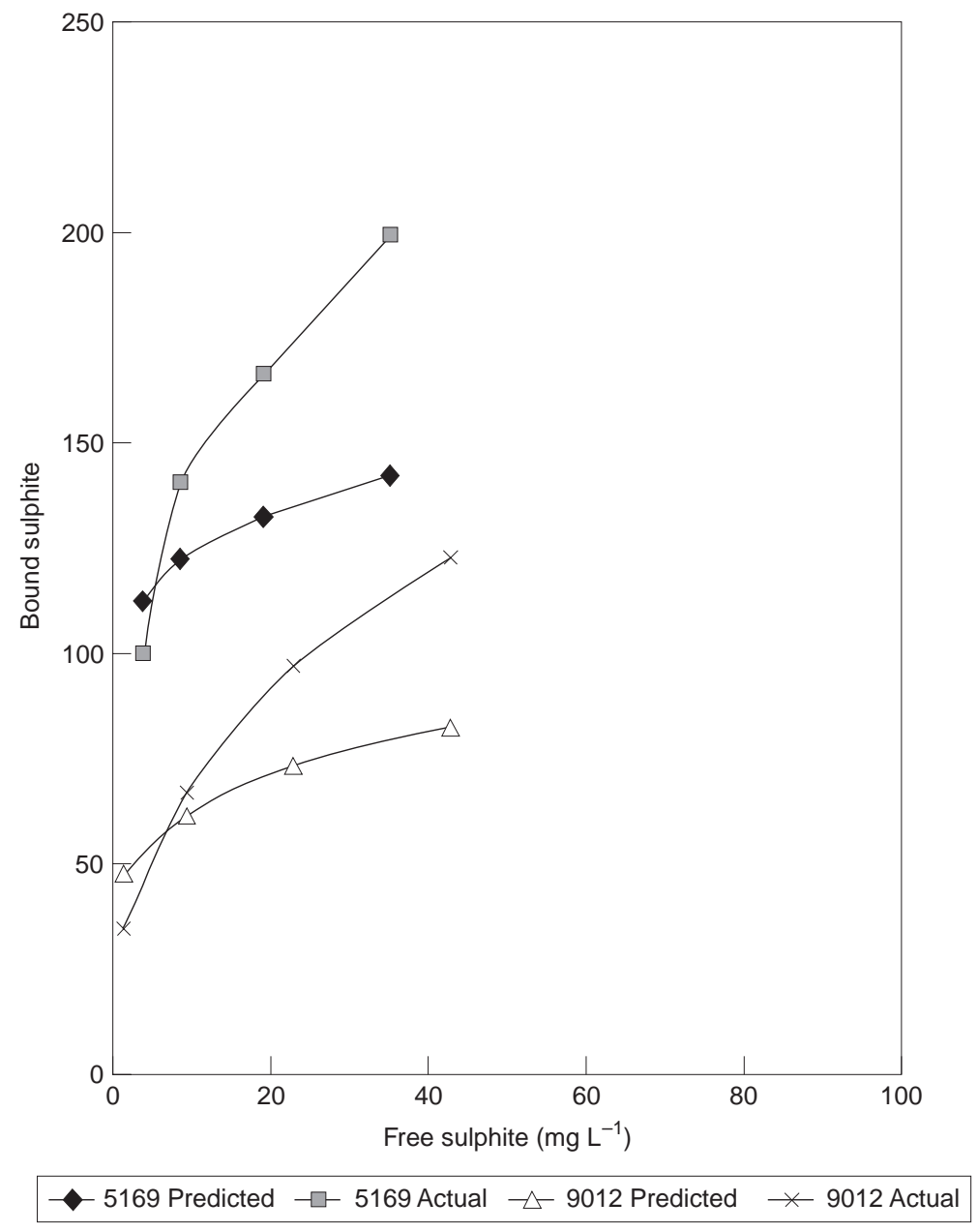

known sulphite binders 5-keto fructose and 2,5 diketogluconic acid which are produced by microbial action. In the absence of authentic standards, however, this could not be confirmed.

Despite the presence of unknown binding compounds in the juice, which might reflect the condition of the original fruit, it is clear that the yeast strains investigated were capable of producing widely varying levels of metabolic carbonyls in the cider.

\section{Controlled fermentations with two yeast strains at three temperatures in the presence and absence of added nutrients}

Fermentation data

Microbiological analysis of the yeast inocula and the fermented ciders showed no evidence for any significant microbial contamination. Most fermentations reached attenuation within 14 days although some attenuated much faster than others (Table 5). In the absence of yeast nutrients, fermentation rates were slower, especially at the lower fermentation temperatures; strain NCYC 3627 fermented more slowly in the absence of nutrients at any of the three temperatures than did strain NCYC 5169. Chemical analysis suggested that NCYC 5169 may be a producer of $\mathrm{SO}_{2}$ especially at the lower temperatures $\left(15\right.$ and $\left.20^{\circ} \mathrm{C}\right)$ and in the presence of yeast nutrients. This was confirmed from the total $\mathrm{SO}_{2}$ data obtained on analysis of the ciders from the previous experiment (Table 4). Because of the need to terminate all fermentations at 14 days, residual gravity was much higher in some fermentations, especially those with NCYC 3627. 


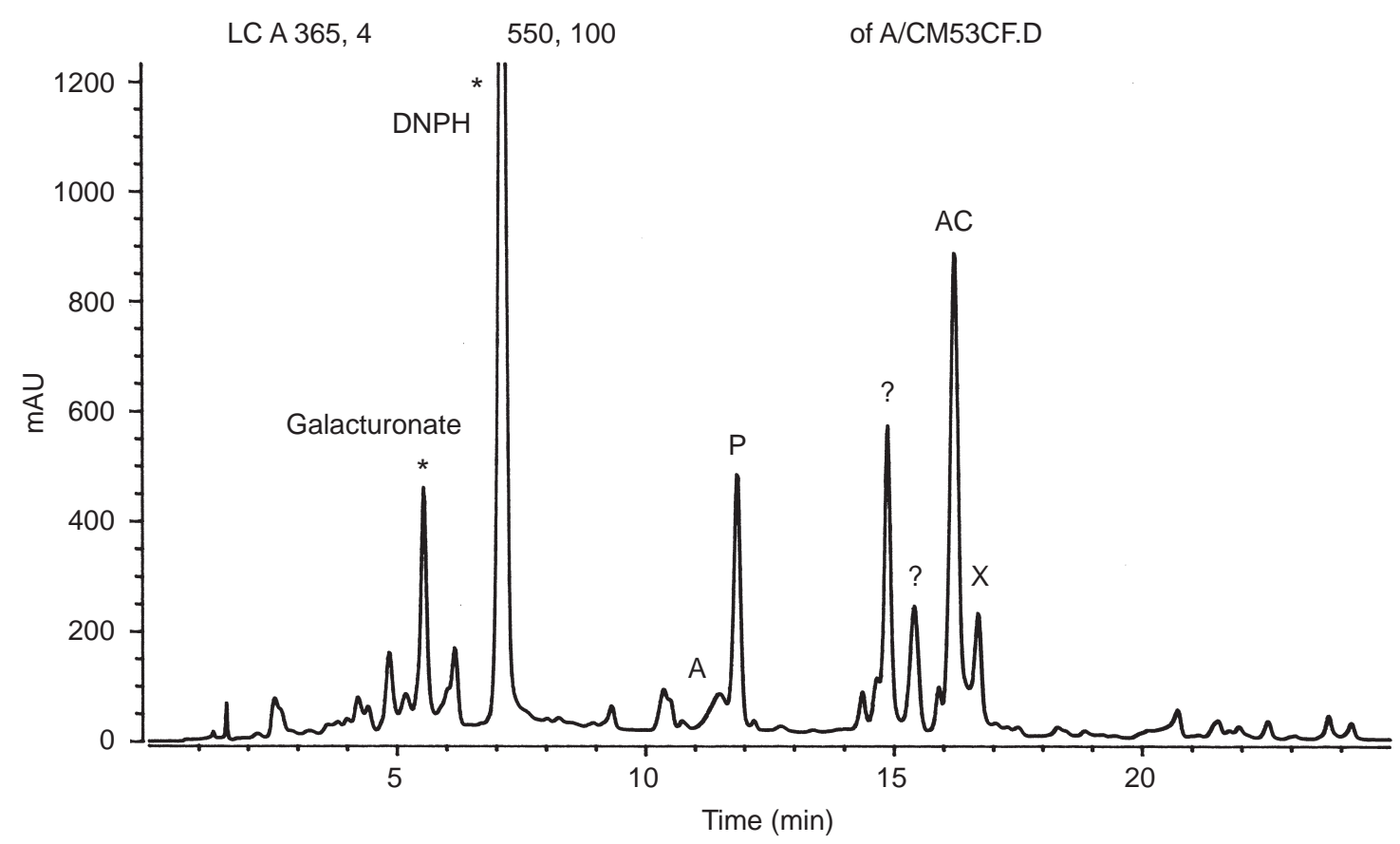

Figure 4 HPLC chromatogram for a fermented cider from 1993 juice. A: $\alpha$-keto glutarate; P: pyruvate; AC: acetaldehyde; X: Lxylosone; ?: unknown carbonyls (described in text).

Analysis of the bottled ciders (Table 6) showed that, in the presence or absence of yeast nutrients, NCYC 5169 produced a similar level of alcohol at all temperatures as did NCYC 3627 in the presence of nutrients. However, in the absence of nutrients, NCYC 3627 produced considerably less alcohol at all temperatures. This correlated with its slower rate of fermentation and the increased content of metabolic carbonyls - presumably their final conversion to ethanol (where thiamine and pantothenate are known to be cofactors) was not so readily accomplished under these conditions. Both strains produced more acid and had lower levels of residual sugar when grown in the presence of added nutrients.

\section{Sulphite binding data}

In this series no measurements of experimental binding power were carried out since attention was focused on the behaviour of the yeast in its

Table 5 Effects of temperature and addition of yeast nutrients on the fermentation performance of two yeast strains

\begin{tabular}{|c|c|c|c|c|c|c|c|}
\hline \multirow[t]{3}{*}{ Yeast strain } & \multirow[t]{3}{*}{ Parameter } & \multicolumn{5}{|c|}{$\begin{array}{l}\text { Fermentation in the presence }(+) \text { or absence }(-) \text { of } \\
\text { nutrients at fermentation temperature of }\end{array}$} & \\
\hline & & \multicolumn{2}{|l|}{$\overline{15^{\circ} \mathrm{C}}$} & \multicolumn{2}{|l|}{$20^{\circ} \mathrm{C}$} & \multicolumn{2}{|l|}{$25^{\circ} \mathrm{C}$} \\
\hline & & + & - & + & - & + & - \\
\hline \multirow[t]{3}{*}{3627} & Attenuation time (days) & 12 & $>14$ & 9 & $\sim 14$ & 14 & 9 \\
\hline & Residual gravity & 2.2 & 4.2 & 1.5 & 2.7 & 1.2 & 2.5 \\
\hline & $\Delta$ Total $\mathrm{SO}_{2}\left(\mathrm{mgL}^{-1}\right)^{*}$ & -6.3 & +1.4 & +1.7 & +4.7 & n.a. & n.a. \\
\hline \multirow[t]{3}{*}{5169} & Attenuation time (days) & 9 & 14 & 7 & 14 & 7 & 11 \\
\hline & Residual Gravity & 2.3 & 1.5 & 1.7 & 1.5 & 1.3 & 1.3 \\
\hline & $\Delta$ Total $\mathrm{SO}_{2}\left(\mathrm{mgL}^{-1}\right)^{*}$ & +52.3 & +28.8 & +33.5 & +22.7 & n.a. & n.a. \\
\hline
\end{tabular}

* Difference between total $\mathrm{SO}_{2}$ level immediately prior to inoculation and at day 14 . 
Table 6 Analytical data on ciders fermented at 15,20 or $25{ }^{\circ} \mathrm{C}$ in the presence or absence of added nutrients

\begin{tabular}{|c|c|c|c|c|c|c|c|}
\hline \multirow[t]{3}{*}{ Yeast strain } & \multirow[t]{3}{*}{ Cider analysis } & \multicolumn{5}{|c|}{$\begin{array}{l}\text { Fermentation in the presence }(+) \text { or absence }(-) \text { of } \\
\text { nutrients at fermentation temperature of }\end{array}$} & \\
\hline & & \multicolumn{2}{|l|}{$\overline{15^{\circ} \mathrm{C}}$} & \multicolumn{2}{|l|}{$20^{\circ} \mathrm{C}$} & \multicolumn{2}{|l|}{$25^{\circ} \mathrm{C}$} \\
\hline & & + & - & + & - & + & - \\
\hline \multirow[t]{8}{*}{3627} & Alcohol $(\% \mathrm{v} / \mathrm{v})$ & 5.37 & 5.00 & 5.53 & 5.11 & 5.42 & 5.00 \\
\hline & Total acidity $\left(\mathrm{g} \mathrm{L}^{-1}\right)$ & 5.18 & 4.85 & 5.15 & 4.56 & 5.41 & 4.55 \\
\hline & $\begin{array}{l}\text { Residual sugar } \\
(\% \mathrm{w} / \mathrm{v} \text { as sucrose) }\end{array}$ & 0.48 & 1.10 & 0.33 & 0.66 & 0.25 & 0.87 \\
\hline & SG (degrees Sacch) & 1.8 & 4.2 & 2.0 & 2.9 & 1.1 & 3.6 \\
\hline & $\begin{array}{l}\alpha \text {-keto glutarate } \\
\left(\mathrm{mg} \mathrm{L}^{-1}\right)\end{array}$ & 38 & 110 & 44 & 93 & 78 & 157 \\
\hline & pyruvate $\left(\mathrm{mg} \mathrm{L}^{-1}\right)$ & 44 & 133 & 23 & 73 & 28 & 86 \\
\hline & acetaldehyde $\left(\mathrm{mg} \mathrm{L}^{-1}\right)$ & 23 & 35 & 14 & 20 & 10 & 15 \\
\hline & $\begin{array}{l}\text { Bound } \mathrm{SO}_{2} \text { at } \\
45 \mathrm{mg} \mathrm{L}^{-1} \text { free }\end{array}$ & 69 & 156 & 45 & 95 & 50 & 110 \\
\hline \multirow[t]{8}{*}{5169} & Alcohol $(\% \mathrm{v} / \mathrm{v})$ & 5.34 & 5.48 & 5.54 & 5.53 & 5.35 & 5.43 \\
\hline & Total acidity $\left(\mathrm{g} \mathrm{L}^{-1}\right)$ & 5.26 & 5.05 & 7.08 & 4.96 & 6.3 & 4.96 \\
\hline & $\begin{array}{l}\text { Residual sugar } \\
(\% \mathrm{w} / \mathrm{v} \text { as sucrose })\end{array}$ & 0.39 & 0.48 & 0.29 & 0.42 & 0.29 & 0.53 \\
\hline & SG (degrees Sacch) & 2.4 & 1.0 & 2.2 & 1.8 & 2.4 & 1.3 \\
\hline & $\begin{array}{l}\alpha \text {-keto glutarate } \\
\left(\mathrm{mg} \mathrm{L}^{-1}\right)\end{array}$ & 34 & 59 & 42 & 93 & 35 & 108 \\
\hline & pyruvate $\left(\mathrm{mg} \mathrm{L}^{-1}\right)$ & 87 & 69 & 57 & 73 & 58 & 95 \\
\hline & acetaldehyde $\left(\mathrm{mg} \mathrm{L}^{-1}\right)$ & 53 & 39 & 36 & 20 & 45 & 25 \\
\hline & $\begin{array}{l}\text { Bound } \mathrm{SO}_{2} \text { at } \\
45 \mathrm{mg} \mathrm{L}^{-1} \text { free }\end{array}$ & 137 & 112 & 96 & 95 & 108 & 119 \\
\hline
\end{tabular}

production of metabolic carbonyls under different conditions. The HPLC data (Table 6) were used to give curves of predicted binding power. It was immediately evident that NCYC 3627 always gave the lowest binding power (irrespective of temperature) when it was supplied with nutrients. However, in the absence of nutrients, its binding power was twice as high and was similar to that of NCYC 5169 (whose binding power was independent of nutrient supply). These effects were rationalized on the basis of the detailed composition of acetaldehyde, pyruvate and $\alpha$-keto glutarate in each case. It appeared that NCYC 3627 was unable to synthesize its own cofactors (e.g. thiamin) for the conversion of pyruvate to acetaldehyde (and thence to ethanol) whereas NCYC 5169 accumulated acetaldehyde even when nutrients were supplied. The tendency of this yeast (NCYC 5169) to synthesise sulphite de novo may also be a contributory factor.

In practice, the lowest sulphite binding was achieved using strain NCYC 3627 with the addition of nutrients. There was no clear effect of tempera- ture. Samples of part fermented ciders were also analyzed, but no clear differences were discernible except in one set where the results were similar to those already described.

\section{Controlled fermentation of bright and cloudy, culinary and bittersweet juice bases prepared from fresh and concentrated apple juices}

\section{Fermentation data}

The data are summarized in Table 7. The fresh juice bittersweet (BS) fermentations attenuated more rapidly than did the $\mathrm{BS}$ concentrated juice fermentations; by contrast there was no difference between the fresh and concentrated culinary juices. Clear juices all attenuated more rapidly than did the corresponding cloudy juices. In all cases, the residual gravity was lower in the fermented fresh juices than in the concentrates, but the fall in total $\mathrm{SO}_{2}$ was greater in the concentrate fermentations than in the fresh juice fermentations. There was little difference in the fall in free $\mathrm{SO}_{2}$ levels in the different fermentations. A 
Table 7 Summary of data from cider fermentations using different juices

\begin{tabular}{|c|c|c|c|c|c|c|c|c|}
\hline \multirow[t]{3}{*}{ Parameter } & \multicolumn{4}{|c|}{ Bittersweet juice } & \multicolumn{4}{|c|}{ Culinary juice } \\
\hline & \multicolumn{2}{|l|}{ Cloudy } & \multicolumn{2}{|l|}{ Clear } & \multicolumn{2}{|l|}{ Cloudy } & \multicolumn{2}{|l|}{ Clear } \\
\hline & Fresh & Conc & Fresh & Conc & Fresh & Conc & Fresh & Conc \\
\hline Attenuation time (days) & 12 & 16 & 11 & 14 & 15 & 14 & 9 & 9 \\
\hline Residual gravity & 0.9 & 2.0 & 0.9 & 1.0 & 0.83 & 1.0 & 0.38 & 0.90 \\
\hline$\Delta$ Total $\mathrm{SO}_{2}\left(\mathrm{mg} \mathrm{L}^{-1}\right)^{*}$ & -40 & -88 & -40 & -33 & -10 & -31 & -3 & -8 \\
\hline$\Delta$ Free $\mathrm{SO}_{2}\left(\mathrm{mg} \mathrm{L}^{-1}\right)^{*}$ & -30 & -27 & -26.8 & -25 & -24 & -22 & -28 & -28 \\
\hline$\Delta$ Total acidity $\left(\mathrm{mg} \mathrm{L}^{-1}\right)^{*}$ & +15 & +9 & -4 & +12.1 & -14.4 & -9.6 & -1.6 & -5.3 \\
\hline$\Delta$ Volatile acidity $\left(\mathrm{mg} \mathrm{L}^{-1}\right)^{*}$ & +0.06 & +0.5 & +0.04 & +0.11 & +0.25 & +0.26 & +0.33 & +0.31 \\
\hline
\end{tabular}

* Change in total or free $\mathrm{SO}_{2}$, total acidity and volatile acidity between time of inoculation and attenuation of the cider

major difference observed was a significant increase in total acidity in 3 of the 4 BS fermentations whereas there was a fall in total acidity in all culinary juice fermentations. Some differences were observed also between the final levels of volatile acidity in the BS fermentations (greater increase in the fermented concentrates) but no differences in the culinary juice fermentations. Analytical data on the fined, pasteurized ciders are summarized in Table 8 . The level of alcohol in the culinary ciders (mean $5.85 \pm 0.16 \% \mathrm{v} /$ v) was greater than in the BS ciders $(5.70 \pm 0.21 \% \mathrm{v} /$ v) but the difference was statistically insignificant $(P$ $>0.20)$. As would be expected, the total acidity in the culinary ciders $\left(68.3 \pm 4.1 \mathrm{mg} \mathrm{L}^{-1}\right)$ was significantly greater $(P<0.01)$ than that in the BS ciders $\left(36 \pm 4.1 \mathrm{mg} \mathrm{L}^{-1}\right)$ but the levels of volatile acidity in the culinary and BS ciders $(0.39 \pm 0.09$ $\mathrm{mg} \mathrm{L}^{-1}$ and $0.28 \pm 0.04 \mathrm{mg} \mathrm{L}^{-1}$, respectively) were not significantly different $(P>0.05)$.
Sulphite binding data

The binding curves for the culinary juice fermentations were similar to those obtained previously using the same yeast at the same temperature. At a free $\mathrm{SO}_{2}$ of $45 \mathrm{mg} \mathrm{L}^{-1}$, the bound $\mathrm{SO}_{2}$ ranged from 116 to 160 $\mathrm{mg} \mathrm{L}^{-1}$; in the BS fermentations the overall binding power was much higher (131-217 $\mathrm{mg} \mathrm{L}^{-1}$ at 45 $\mathrm{mg} \mathrm{L}^{-1}$ free $\mathrm{SO}_{2}$ ) with the cloudy concentrate giving the highest binding and the clear concentrate giving the lowest. There is no immediate explanation why bittersweet juice fermentations should give generally higher values of binding than those of culinary juice, unless some component of the juice (e.g. polyphenols) influences the way in which the metabolism of the yeast carbonyls takes place.

\section{Discussion and conclusions}

The purpose of these studies was to ascertain the

Table 8 Analytical data on ciders produced from the different juices

\begin{tabular}{|c|c|c|c|c|c|c|c|c|}
\hline \multirow[t]{3}{*}{ Parameter } & \multicolumn{4}{|c|}{ Bittersweet juice } & \multicolumn{4}{|c|}{ Culinary juice } \\
\hline & \multicolumn{2}{|l|}{ Cloudy } & \multicolumn{2}{|l|}{ Clear } & \multicolumn{2}{|l|}{ Cloudy } & \multicolumn{2}{|l|}{ Clear } \\
\hline & Fresh & Conc & Fresh & Conc & Fresh & Conc & Fresh & Conc \\
\hline Alcohol $(\% \mathrm{v} / \mathrm{v})$ & 5.81 & 5.82 & 5.77 & 5.39 & 5.98 & 5.68 & 5.99 & 5.73 \\
\hline Total acidity $\left(\mathrm{g} \mathrm{L}^{-1}\right)$ & 37 & 38 & 30 & 39 & 72 & 64 & 69 & 68 \\
\hline Volatile acidity $\left(\mathrm{g} \mathrm{L}^{-1}\right)$ & 0.23 & 0.26 & 0.29 & 0.32 & 0.28 & 0.36 & 0.46 & 0.46 \\
\hline $\begin{array}{l}\text { Residual sugar } \\
\text { (\% w/v as sucrose) }\end{array}$ & 0.84 & 0.70 & 2.06 & 0.57 & 0.76 & 0.96 & 0.84 & 0.72 \\
\hline$\alpha$-Ketoglutarate $\mathrm{mg} \mathrm{L}^{-1}$ & 138 & 100 & 41 & 119 & 140 & 96 & 72 & 70 \\
\hline Pyruvate $\mathrm{mg} \mathrm{L}^{-1}$ & 173 & 161 & 139 & 101 & 84 & 70 & 77 & 76 \\
\hline Acetaldehyde $\mathrm{mg} \mathrm{L}^{-1}$ & 40 & 67 & 60 & 29 & 53 & 35 & 46 & 47 \\
\hline $\begin{array}{l}\text { Sulphite binding at } \\
45 \mathrm{mg} \mathrm{L}^{-1} \text { free } \mathrm{SO}_{2}\end{array}$ & 195 & 217 & 179 & 131 & 160 & 116 & 130 & 130 \\
\hline
\end{tabular}


factors affecting the binding of sulphite by constituents of apple juice and cider. Analytical procedures developed as part of this project by Lea et al. (2000) were used to measure the binding power of a range of commercial cider products in two ways. Firstly, through the experimental determination of bound and free sulphite after equilibration with four added levels of sulphite; secondly, through HPLC analysis of the binding carbonyls in the cider followed by calculation of their contribution to the sulphite binding power. Experimental results demonstrated a good agreement between the two methods in eight of the commercial ciders examined. In three ciders the experimentally determined binding power was significantly higher than the levels predicted by the carbonyl analyses; this was considered to be owing, in part, to the presence of L-xylosone in the ciders. However, other possible causes of binding may include the use of anthocyanins, azo-dyes and caramel colouring agents, saccharin, hydroxymethyl-furfural (from poor quality concentrates) and the occurrence of keto sugars from poor quality fruit.

In the remaining case the sulphite binding power was so high that neither method yielded sensible results - this was later attributed to the use of ascorbic acid in the cider which would have blocked the fermentation process with the accumulation of excessive quantities of pyruvate and acetaldehyde. Such an effect is known to occur if sulphite is added to an actively fermenting yeast (Hammond \& Carr, 1976), but it is not clear if a similar mechanism operates in this case. Of the eight ciders for which good agreement was achieved, it was possible to explain the binding of sulphite by the presence of the known carbonyls. A critical conclusion was that galacturonic acid may be of much greater significance than had previously been believed, due to increased use of depectinization processes in the preparation of apple juice concentrates.

The study demonstrates unequivocally that the sulphite binding power of ciders is dependent upon the strain of fermentation yeast, one strain (NCYC 5169) producing nearly twice the binding power of the least able strain (NCYC 3627). Hence, in seeking to minimize the production of binding compounds, the selection of yeast strain is of considerable importance. There was a moderate correlation between sulphite binding power in the cider and the rate of fermentation - yeasts with a high fermentative capacity, which reached attenuation quickly (e.g. NCYC 5169), tended to produce ciders with greater sulphite binding power. The extent of binding, as reflected in the shapes of the curves was much greater in the experimental ciders than had been observed in the commercial products - probably reflecting the fact that the experimental ciders were made from $100 \%$ juice. The ciders contained significant quantities of unknown binding compounds which could not be attributed to additives, pasteurization or concentration processes since none were used. It is probable that they reflect the presence of sulphite binding compounds derived from poor quality (e.g. mould damaged) fruits.

When ciders were fermented using the strongest and weakest producers of sulphite binding compounds, it was clear that strain NCYC 3627 always produced the lower level of sulphite binding when it was provided with added nutrients, but in the absence of nutrients its binding power was significantly increased and did not differ from that of ciders produced by strain NCYC 5169. This observation is in accord with existing knowledge since the addition of thiamin and/or pantothenate is known to lower the accumulation of pyruvate and acetaldehyde in susceptible yeast strains (Whiting, 1976; Würdig, 1989; Beech, 1993).

Although there was no overall effect of fermentation temperature, examination of the data shows a consistent trend whereby strain NCYC 3627 produces significantly more pyruvate and acetaldehyde at $15{ }^{\circ} \mathrm{C}$ and more $\alpha$-keto glutarate at $25{ }^{\circ} \mathrm{C}$ than at the other temperatures, regardless of the presence or absence of nutrients, although sulphite binding levels were consistently higher in the absence of added nutrients than in their presence. The sulphite binding capacity of the NCYC 3627 cider was greater when fermented at $15{ }^{\circ} \mathrm{C}$ than at the other temperatures. Similarly, strain NCYC 5169 produced more $\alpha$-keto glutarate and pyruvate at $20{ }^{\circ} \mathrm{C}$ and more acetaldehyde at $15^{\circ} \mathrm{C}$ than at the other temperatures. For this strain, sulphite binding power was higher at $15^{\circ} \mathrm{C}$ and $25{ }^{\circ} \mathrm{C}$ than at $20{ }^{\circ} \mathrm{C}$.

It is of interest that the yeast strains with the highest and lowest sulphite binding capacity were also the highest and lowest producers of sulphite respectively during fermentation (where sulphate is presumably used as a source). Indeed there was a general correlation between sulphite binding and sulphite production across all 12 yeast strains. 


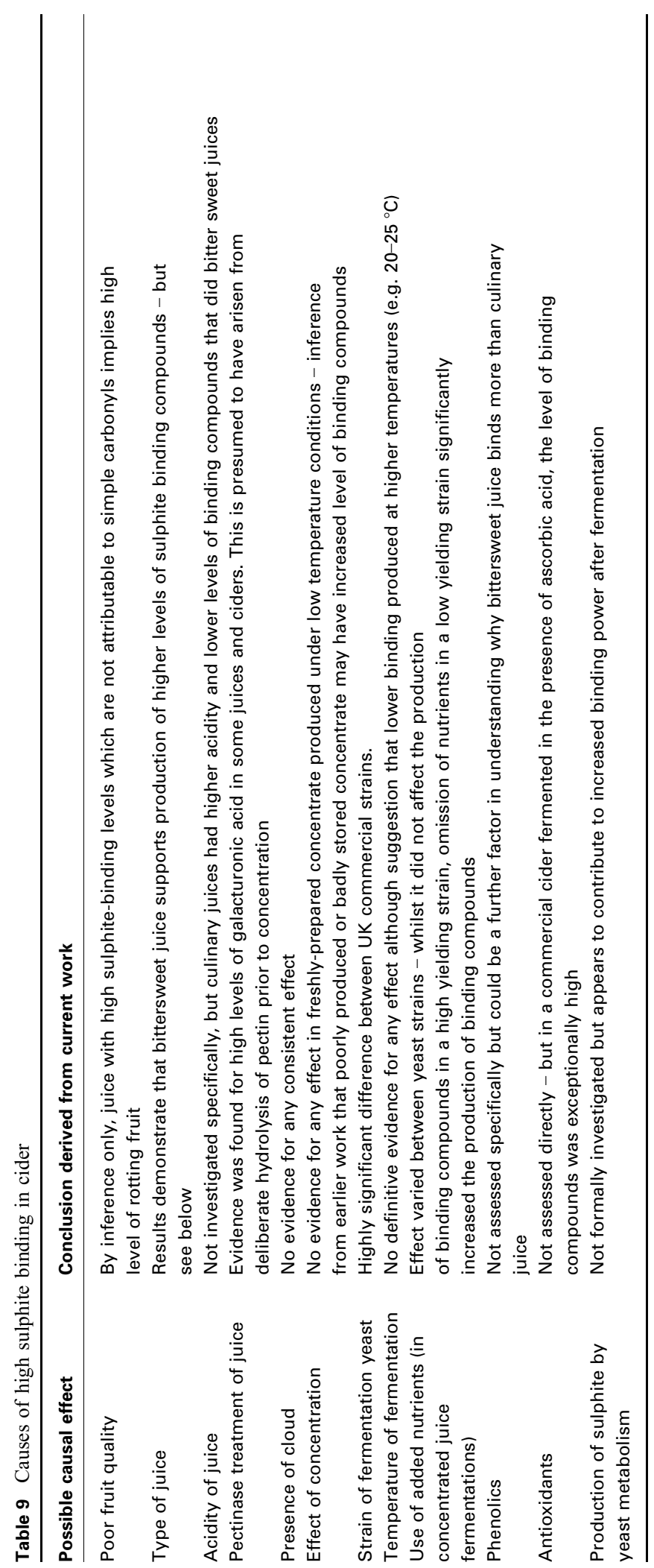

International Journal of Food Science and Technology 2000, 35, 113-127 
According to Würdig (1989) this is the same mechanism responsible for the increased aldehyde production following the addition of exogenous sulphite to an active fermentation. The binding of acetaldehyde by sulphite as it is formed, and the consequent blockage of the conversion pathway to ethanol, induces accumulation, rather than metabolism of acetaldehyde.

In the experiments using fresh and concentrated bittersweet and culinary juices fermented at $20{ }^{\circ} \mathrm{C}$ the overall binding power of the ciders was similar to that observed previously with the yeast strain NCYC 5169. There was no clear pattern of difference between the juices except that ciders made from bittersweet juice had significantly higher levels of sulphite binding compounds than did the culinary juice ciders. In three of the four sets, the cloudy juice and concentrate ciders had higher binding levels than did the clear juice ciders; similarly, in three of the sets the fresh juice ciders had higher levels of binding compounds than the concentrate derived ciders. However, the differences were not statistically significant.

In the early stages of the project a range of factors was identified which might be expected to increase the level of sulphite binding compounds in cider. For practical and economic reasons it was not possible to investigate all the possibilities. Table 9 provides a summary of these possible factors and the findings from the present series of investigations.

\section{Acknowledgments}

These investigations were funded by the National Association of Cider Makers (NACM) to whom we are indebted for permission to publish this report. All fermentations were carried out at the Brewing Research International, Nutfield, Surrey; we are grateful to the various members of staff who carried out the fermentations and related analyses. Apple juices and other fermentation materials were supplied by member companies of the NACM. We are indebted to Martin Forster of H P Bulmer Ltd who organized the supply of fresh BS and culinary juices and prepared the concentrated juices in the pilot plant at Leatherhead Food RA. Analytical support at RSSL was provided by Graeme Ford and Sue Fowler whose assistance is hereby acknowledged.

\section{References}

Beech, F.W. (1993). Yeasts in cider making. In: The Yeasts, vol. 5 - Yeast Technology, 2nd edn, (edited by A.H. Rose and J.S. Harrsion). Pp. 169-214. London: Academic Press.

Beech, F.W., Burroughs, L.F., Timberlake, C.F. \& Whiting, G.C. (1979). Current progress in the chemical aspects and antimicrobial effects of sulphur dioxide $\left(\mathrm{SO}_{2}\right)$. Bulletin de L'O I V, 52, 1001-1022.

Beech, F.W. \& Davenport, R.R. (1983). New Prospects and Problems in the Beverage Industry. In: 'Food Microbiology: Advances and Prospects' (edited by T.A. Roberts and F.A. Skinner). Pp. 241-256. London: Academic Press.

Beech, F.W. \& Jarvis, B. (1989). The need for sulphur dioxide in UK cider production. NACM Submission to MAFF.

Burroughs, L.F. \& Sparks, A.H. (1962). The effect of condition of fruit on the sulphur dioxide binding power of cider. Annual Report of the Long Ashton Research Station for 1962, pp. 151-156. University of Bristol, UK.

Burroughs, L.F. \& Sparks, A.H. (1964). The identification of sulphur dioxide binding compounds in apple juices and ciders. Journal of the Science of Food and Agriculture, 15, 176-185.

Burroughs, L.F. \& Sparks, A.H. (1973a). Sulphite-binding power of wines and ciders I. Equilibrium constants for the dissociation of carbonyl bisulphite compounds. Journal of the Science of Food and Agriculture, 24, 187-198.

Burroughs, L.F. \& Sparks, A.H. (1973b). Sulphite-binding power of wines and ciders II. Theoretical considerations and calculation of sulphite-binding equilibria. Journal of the Science of Food and Agriculture, 24, 199-206.

Burroughs, L.F. \& Sparks, A.H. (1973c). Sulphite-binding power of wines and ciders III. Determination of carbonyl compounds in a wine and calculation of its sulphite-binding power. Journal of the Science of Food and Agriculture, 24, 201-217.

Evelyn, J. (1664). Pomona, or an appendix concerning fruit trees, in relation to ciders - the making and several ways of ordering it. London: J. Martyn and J. Allestry.

Hammond, S.M. \& Carr, J.G. (1976). The antimicrobial activity of $\mathrm{SO}_{2}$ - with particular reference to fermented and nonfermented fruit juices. In: Inhibition and Inactivation of Vegetative Microbes, (edited by F.A. Skinner and W.B. Hugo). Pp. 89-110. London: Academic Press.

Lea, A.G.H., Ford, G.D. \& Fowler, S. (2000). Analytical techniques for the estimation of sulphite-binding components in ciders and wines. International Journal of Food Science and Technology, 35, 105-112.

NACM (1996). Handbook of Analytical Methods. London: National Association of Cider Makers.

Whiting, G.C. (1976). Organic acid metabolism during fermentation of alcoholic beverages - a review. Journal of the Institute of Brewing, 82, 84-92.

Whiting, G.C. \& Coggins, R.A. (1960). Formation of Lxylosone from ascorbic acid. Nature, 185, 843-844.

Würdig, G. (1989). Behandlung des Weines mit schwefliger Säure. In: Chemie Des Weines (edited by G. Würdig and H. Woller) Pp. 329-370. Stuttgart: Ulmer-Verlag. 